\title{
Naltrexone extended-release injection: an option for the management of opioid abuse
}

\author{
Robert Taylor Jr' \\ Robert B Raffa ${ }^{2}$ \\ Joseph V Pergolizzi Jr $r^{3,4}$ \\ 'NEMA Research Inc, Naples, FL, \\ ${ }^{2}$ Department of Pharmaceutical \\ Sciences, Temple University School \\ of Pharmacy, Philadelphia, PA, \\ ${ }^{3}$ Department of Medicine, Johns \\ Hopkins University School of \\ Medicine, Baltimore, MD, ${ }^{4}$ Department \\ of Anesthesiology, Georgetown \\ University School of Medicine, \\ Washington, DC, USA
}

This article was published in the following Dove Press journal:

Substance Abuse and Rehabilitation

5 December 2011

Number of times this article has been viewed

\begin{abstract}
The United States Food and Drug Administration (FDA) approved naltrexone, a synthetic competitive antagonist at opioid receptors, in oral form in 1984 for use in the management of opioid abuse and addiction. Because naltrexone and its major metabolite, 6 - $\beta$-naltrexone, are both competitive antagonists at opioid receptors - and thereby inhibit opioid agonist-induced effects including those desired by abusers - it was hypothesized that once maintained on naltrexone, opioid-induced desirable effects would be diminished to the point that relapse to illicit use would decline because it was no longer rewarding. However, good medication compliance is a requisite for such a strategy to be effective and a systematic review of oral naltrexone concluded that this method of treatment was not superior for any outcomes measured (ie, retention, abstinence, or side effects) to placebo, psychotherapy, benzodiazepines, or buprenorphine treatment. In addition, the retention rate on oral naltrexone was very low (less than $30 \%$ ). Recently, the FDA approved an extended-release formulation (intramuscular depot injection) of naltrexone for prevention of relapse to opioid dependence following opioid detoxification and to be used along with counseling and social support. Since it needs to be administered only monthly, as opposed to the daily administration required for the oral formulation, naltrexone injection has the potential for increasing adherence and retention rates. Concerns include liver damage at high doses (oral formulation) and possible opioid overdose if an attempt is made to surmount receptor antagonism by taking higher doses of an opioid agonist or if opioid receptors become "sensitized" under long-term antagonism. The focus of the present review is the current information regarding the safety and efficacy of naltrexone extended-release therapy.
\end{abstract}

Keywords: opioid dependence, relapse prevention, depot injection, extended-release naltrexone

\section{Introduction \\ Incidence and prevalence of opioid abuse}

The rate of both illicit and prescription drug misuse and abuse has steadily risen throughout the United States. According to the 2009 National Survey on Drug Use and Health report, illicit drug use (eg, cocaine and heroin) grew from $8.3 \%$ in 2002 to $8.9 \%$ in 2010 in persons aged 12 years or older. ${ }^{1}$ In addition, the efforts by health care providers to provide better treatments for pain have consequently caused a rise in misuse, abuse, addiction, and diversion of many prescription opioids. ${ }^{2}$ A prime example of the misuse and abuse of prescription opioids occurred in the state of Florida, where the death rate for prescription drugs increased approximately $84 \%$, from 7.3 to 13.4 per 100,000 of the population from 2003 to 2009, with the greatest increase for prescription oxycodone $(264.6 \%)$, methadone $(79.2 \%)$, hydrocodone $(34.9 \%)$, and 
morphine $(26.2 \%) .{ }^{3}$ Since the effects of opioid abuse can go beyond the individual and cause multiple social, economic, and health problems, ${ }^{4-6}$ effective treatment options are critical for both the illicit drug and prescription opioid abuser.

\section{Management of opioid abuse}

Opioid abuse can be a lifelong battle that requires substantial resources and therapeutic efforts by the patient, health care providers, regulatory agencies, and others. Additionally, opioid abusers come from different backgrounds and have different motivations and intentions when it comes to abuse. In an effort to accommodate the entire spectrum of opioid abusers, different prevention methods have been employed by physicians, regulatory bodies, and pharmaceutical companies. In an effort to counter potential short-term abuse, newer formulations of opioid agonists have come onto the market in order to make the product more tamper resistant and/or less desirable or appealing to abusers. ${ }^{7-9}$ Many extended-release formulations (eg, Remoxy ${ }^{\circledR}$, King Pharmaceuticals, Inc, Cary, NC; Acuracet ${ }^{\circledR}$, Acura Pharmaceuticals, Inc, Palatine, IL; Exalgo ${ }^{\circledR}$, Mallinckrodt Inc, Hazelwood, MO) in addition to tamper-resistant (eg, Embeda $^{\circledR}$, Alpharma Pharmaceuticals LLC, Bridgewater, NJ) and dependence-deterrent formulations (Oxytrex ${ }^{\circledR}$, Pain Therapeutics, Inc, San Francisco, CA; Suboxone ${ }^{\circledR}$, Reckitt Benckiser Pharmaceuticals Inc, Richmond, VA) of agonist-antagonist combinations have been designed as abuse barriers. However, these formulations provide little benefit to the opioid-dependent patients looking to quit longterm abuse and thus these patients require other methods of treatment. Current therapies for opioid-dependent patients include (1) an agonist-based approach such as methadone, buprenorphine, or a buprenorphine-naloxone combination; (2) an antagonist-based approach, which includes the daily administration of the opioid antagonist naltrexone; or (3) a pharmacological approach combined with psychotherapy and patient supervision. The choice of approach is usually based on patient and physician preference along with the patient's past medical and treatment history and even their financial status. ${ }^{10-14}$

\section{Agonist-based approach}

In its simplest form, agonist therapy is a supervised administration of a long-acting opioid receptor agonist with the goal to reduce or eliminate illicit drug use, increase retention in treatment, and help reduce many of the risk factors associated with illicit drug use (crime, infections, and so forth). ${ }^{15,16}$ Current therapies for opioid dependence may consist of methadone (Dolophine ${ }^{\circledR}$, Roxane Laboratories, Inc, Columbus, OH; Methadose ${ }^{\circledR}$, Mallinckrodt Specialty Chemicals Company, St Louis, MO), buprenorphine (Subutex ${ }^{\circledR}$ and Suboxone, Reckitt Benckiser Pharmaceuticals Inc), and the less frequently used levomethadyl acetate. ${ }^{17}$ Methadone treatment was the first treatment to become available (in the 1960s), followed by the use of buprenorphine in doctors' offices around the year 2000. Guidelines put forth by the World Federation of Societies of Biological Psychiatry, ${ }^{16}$ two Cochrane reviews, ${ }^{18,19}$ and the World Health Organization ${ }^{20}$ have concluded that there is an excellent evidence base supporting the efficacy of both methadone and buprenorphine for the treatment of opioid withdrawal and maintenance. Despite evidence of efficacy of agonist therapies, many countries and some US states have made agonist therapies unavailable or have severely restricted their access. ${ }^{21}$ Even when therapies are available, not all patients are eligible or accepted for such treatment, owing to long waiting lists, lack of money or health insurance, or failure to produce a photo identification card on request. ${ }^{22,23}$ Furthermore, not all treatment providers or patients agree on this method of therapy, especially in patients who are young, have short dependence histories, or just do not want to take part in a lengthy detoxification therapy. ${ }^{23}$ In addition, some practitioners are concerned about the side effects associated with long-term use of these opioids (eg, hypogonadism or immune suppression). ${ }^{24,25}$ Even though the agonist approach is effective, the limitations and concerns associated with this therapy have created a need for introducing effective antagonist treatments.

\section{Antagonist-based approach}

Opioid-dependent patients may be placed on an antagonist therapy. Opioid receptor antagonists block the effects generated by opioid agonists without producing any agonist effects of their own (Figure 1). Thus, they have no abuse liability, no overdose potential, and they do not require special waivers to be prescribed. ${ }^{26-28}$ Currently, naltrexone (Depade $^{\circledR}$, Mallinckrodt Specialty Chemicals Company; Revia $^{\circledR}$, Bristol-Myers Squibb Pharma Company, Princeton, NJ) is a recommended opioid antagonist both for opioid withdrawal and for maintenance. Naltrexone therapy may be useful in preventing relapse in patients who have withdrawn from opioids and/or those motivated enough to abstain from opioid use. ${ }^{20}$ However, the effectiveness of the antagonist-based approach has been somewhat disappointing and there is insufficient evidence to unequivocally support the clinical effectiveness of oral naltrexone in the treatment 


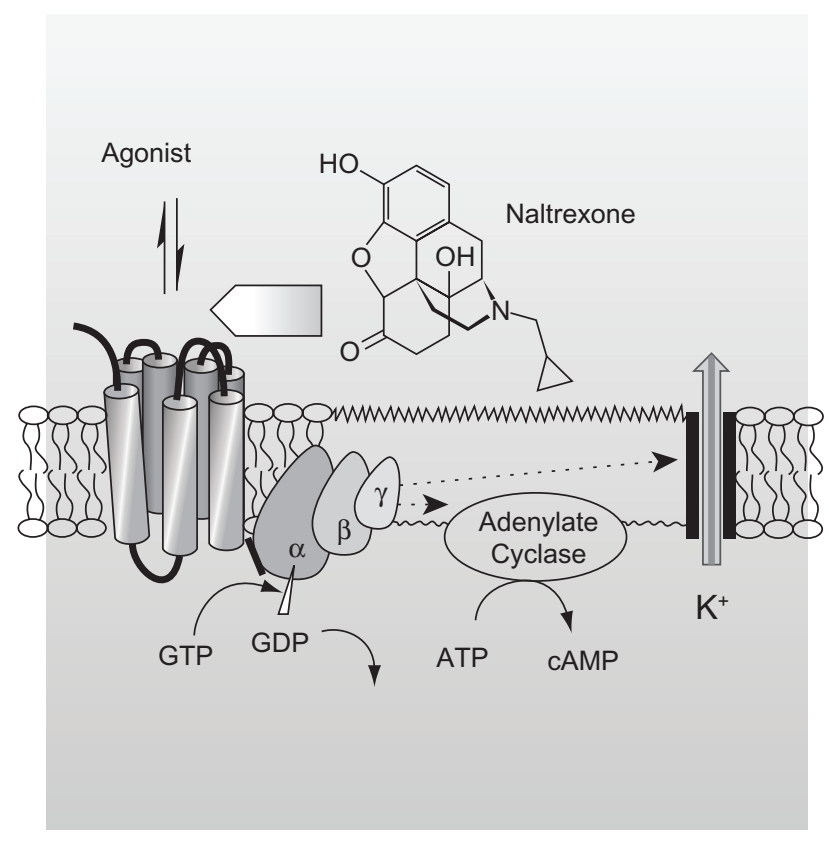

Figure I Mechanism of action of naltrexone. The reversible interaction of an opioid agonist with opioid receptors, which are part of the seven-transmembrane, G-protein-coupled receptor family, elicits opioid-induced effects, including those desired by abusers. Opioid receptor antagonists such as naltrexone also reversibly bind to opioid receptors, but they lack intrinsic activity and thus do not elicit an opioid-like effect. However, their binding limits the number of unoccupied receptors and, consequently, the magnitude of agonist-induced opioid effects. Naltrexone, I7(cyclopropylmethyl)-4,5 $\alpha$-epoxy-3,14-dihydroxymorphinan-6-one, is a substituted oxymorphone (the tertiary amine methyl group is replaced with methylcyclopropane) and the $\mathrm{N}$-cyclopropylmethyl derivative of oxymorphone. Naltrexone's major metabolite, 6- $\beta$-naltrexone, is also a competitive antagonist at opioid receptors. Abbreviations: ATP, adenosine triphosphate; cAmp, cyclic adenosine monophosphate; GDP, guanosine diphosphate; GTP, guanosine triphosphate.

of opioid dependence..$^{29,30}$ Its ineffectiveness can largely be traced to lack of patient adherence and retention. Thus, oral naltrexone has become a therapy mainly for the highly motivated individual.

\section{Pharmacological approach in combination with psychosocial therapy}

In an effort to increase therapy retention rates, increase reduction in illicit opioid use, and help improve patients' quality of life, the concurrent use of psychosocial interventions has been recommended for both agonist and antagonist therapies. ${ }^{20}$ Psychosocial interventions may include cognitive and behavioral approaches, as well as contingency management techniques. A recent systematic review of the literature identified 28 randomly controlled trials that address the advantage of combining psychosocial therapy with agonist maintenance treatments. ${ }^{31}$

When a comparison was made between psychosocial plus maintenance pharmacological treatment and standard maintenance treatment, the results did not indicate any benefit in retention rate (relative risk [RR]: 1.02; 95\% confidence interval $[\mathrm{CI}]: 0.97,1.07)$, opiate use during the treatment (RR: $0.86 ; 95 \%$ CI: 0.65, 1.13), compliance (mean difference [MD]: $0.43 ; 95 \%$ CI: $-0.05,0.92)$, psychiatric symptoms (MD: $0.02 ; 95 \%$ CI: $-0.19,0.23$ ), depression (MD: -1.30 ; 95\% CI: $-3.31,0.72$ ), or number of participants still in treatment at the end of the follow-up (RR: 0.91; 95\% CI: $0.77,1.06$ ). However, the number of participants abstinent at the end of the follow-up showed a benefit in favor of the associated treatment (RR: 1.15; 95\% CI: 1.01 , 1.32). ${ }^{31}$ In addition, psychosocial programs in combination with antagonist treatment have demonstrated effectiveness in maintaining abstinence and retention. ${ }^{32,33}$ For example, in a study with 127 detoxified opioid-dependent patients, patients utilizing both naltrexone treatment and a contingency program versus naltrexone alone showed both treatment retention (7.4 vs 5.6 weeks; $P=0.05$ ) and reduction of opioid use (19 vs 14 opioid-free urine samples; $P=0.04$ ). ${ }^{32}$

Each of the approaches described here has its advantages and its disadvantages; however, underutilization of agonist therapies, unavailability of treatments, and inadequate success rates have created a need for other approaches. The focus of the present review is the current information regarding the safety and efficacy of naltrexone extended-release therapy.

\section{Methods}

The search strategy for the identification of studies included the electronic searching of the PubMed/MEDLINE database, Embase, and The Cochrane Library from database inception through to July 2011. Search terms used individually or in combination included "naltrexone," "extended release naltrexone," "injectable naltrexone," "opioid antagonist," and "opioid dependence." The identified citations were then further limited to any clinical study or review article describing clinical use of injectable extended-release naltrexone. The goal was to present the reader with all published studies regardless of their design type. Studies exclusively describing other forms of naltrexone, including oral or implantable naltrexone, were eliminated. To identify any articles missed by the electronic search, the bibliographies of the electronically identified articles were analyzed and any appropriate articles, based on title and abstract, were retrieved.

\section{Discussion New formulations}

Antagonist approach

Physicians originally had high hopes for antagonist therapies due to the pharmacological profile of these agents in the laboratory. However, clinicians soon realized that the 
effectiveness of the antagonists in the laboratory could not always be duplicated so readily in the clinic. Because the antagonist approach relies so heavily on motivated and conscientious individual to maintain good compliance, a requirement of multiple oral dosing can represent a significant impediment to achieving successful treatment. In an effort to abrogate the problem of patient noncompliance with oral dosing, extended-release, injectable (depot) formulations of the antagonist naltrexone have been developed by three companies. Such an approach would seem to be a desirable method for delivering an opioid antagonist to opioid-dependent patients. ${ }^{34}$

\section{Extended-release naltrexone formulations}

Currently there are three depot injection formulations available for extended-release naltrexone treatment, each providing therapeutic blood levels for approximately 4 weeks. There are two that have not yet been approved by the US Food and Drug Administration (FDA): Depotrex ${ }^{\circledR}$ (Biotek Inc, Woburn, MA) and Naltrel ${ }^{\circledR}$ (DrugAbuse Sciences SAS, Paris, France). Vivitrol ${ }^{\circledR}$ (Alkermes, Waltham, MA) was originally approved for alcohol dependence and received FDA approval for opioid dependence in late 2010. In addition to these depot extended-release injection formulations, biodegradable polylactic acid-based polymer naltrexone implant formulations are currently under investigation. ${ }^{35-38}$ The clinical safety and efficacy of these implants are beyond the scope of this review; rather, focus will be on the extendedrelease injection formulation.

\section{Extended-release naltrexone: efficacy studies}

Comer et $\mathrm{al}^{39}$ examined the safety and efficacy of $192 \mathrm{mg}$ $(n=6)$ and $384 \mathrm{mg}(\mathrm{n}=6)$ doses of a sustained-release naltrexone (Depotrex) on twelve heroin-dependent patients in an 8-week inpatient study. After a 1-week detoxification period, participants were treated with either dose of naltrexone, followed by 6 weeks of challenge with heroin $(0,6.25,12.5,18.75,25 \mathrm{mg}$, intravenously). Various subjective, performance, and physiological effects were measured before and after the heroin administration. Both doses of sustained-release naltrexone antagonized the heroininduced subjective, performance, and physiological effects; the $192 \mathrm{mg}$ dose did so for up to 3 weeks, and the $384 \mathrm{mg}$ dose for up to 5 weeks. In addition, participants did not experience any major side effects except discomfort associated with the initial injection of the naltrexone. These initial results seemed promising for a new treatment therapy.
In a second study, Comer et $\mathrm{al}^{40}$ conducted a doubleblind, 8-week randomized trial on 60 heroin addicts. During weeks 1 and 5, participants received a single injection of placebo or extended-release naltrexone (Depotrex; either $192 \mathrm{mg}$ or $384 \mathrm{mg}$ ) in addition to biweekly preventive therapy sessions. The main outcome measures included retention of treatment and percentage of opioid-negative urine samples. At the end of 8 weeks, 39\% (7/18) of those treated with placebo, $60 \%(12 / 20)$ of those treated with naltrexone $192 \mathrm{mg}$, and 68\% (15/22) of those treated with naltrexone $384 \mathrm{mg}$ remained in the treatment. There were also statistically significant differences $(P<0.002)$ in mean dropout time in the placebo group (27 days), the naltrexone $192 \mathrm{mg}$ group (36 days), and the naltrexone $384 \mathrm{mg}$ group (48 days). When urine samples were tested for traces of opioids, differences were noted between the placebo $(25.3 \%)$ and naltrexone $192 \mathrm{mg}$ (47.1\%) groups and between the placebo and naltrexone $384 \mathrm{mg}$ (61.9\%) groups; however, when adjusted for missed visits or samples, the differences were not statistically significant $(P=0.85)$. Although patients in the naltrexone groups reported "needing heroin less," there was no difference in those "wanting heroin." Similar to the previous study, side effects included induration (hardness) and pain at the injection site.

Brooks et $\mathrm{al}^{41}$ utilized a quasi-experimental uncontrolled design to analyze and compare extended-release and oral naltrexone. At the time there was no study with a head-to-head comparison of investigative depot formulations and approved oral naltrexone. In this study, Brooks et al analyzed treatment retention and opioid use in heroindependent patients during an 8-week period where patients were treated with either long-acting injectable naltrexone or oral naltrexone with psychosocial intervention. In Comer et al's ${ }^{40}$ injectable naltrexone study already described, patients receiving injectable naltrexone $(n=42)$ remained on the treatment longer than patients on oral naltexone $(\mathrm{n}=69)(42.3$ vs 31.9 days; $P=0.012$ ) after 8 weeks. During the 8 weeks of detoxification, injectable naltrexone patients had a similar level of negative urine tests to those in the oral naltrexone group (55\% vs 50\%). However, when missing urine samples were considered positive, injectable naltrexone patients had statistically fewer positive urine tests than the oral naltrexone patients $(P=0.024)$. No patient in these studies was seen to attempt overriding naltrexone. Even though the results of this study point to extended-release naltrexone as superior to oral naltrexone, the analytical approach should be considered exploratory; a true comparative trial is lacking. 
Krupitsky et $\mathrm{al}^{42}$ assessed the efficacy and safety of extended-release injectable naltrexone $380 \mathrm{mg}$ (Vivitrol) in 250 opioid-dependent patients. The primary end points were urine drug tests and self-reporting of abstinence during weeks 5-24. Secondary end points consisted of self-reported opioid-free days, opioid-craving scores, number of days of retention, and relapse. During weeks 5-24, a median of $90 \%$ were confirmed abstinent weeks (by urine analysis) in the treatment group, compared with $35 \%$ in the placebo group $(P=0.0002)$. Those in the treatment group self-reported a median of $99 \%$ opioid-free days, compared with $60 \%$ reported by the placebo group. In addition, there were statistically significant differences $(P<0.0001)$ between the naltrexone and the placebo groups in craving reduction (mean score $=-10.1$ vs 0.7 , respectively) and retention (median $=168$ vs 96 days, respectively; $P=0.0042$ ). During the 24-week study, more participants in the naltrexone group experienced one or more adverse events (including nasopharyngitis, insomnia, hypertension, influenza, pain at the injection site, toothache, and headache) than in the placebo group. There were no overdose events, suicide attempts, or deaths reported.

A retrospective study by Fishman et $\mathrm{al}^{43}$ analyzed an open-label case series to assess acceptability, feasibility, and preliminary outcomes in opioid-dependent adolescents and young adults (average age 18.5 years) using extendedrelease naltrexone (Vivitrol) once every 4 weeks. Primary end points consisted of number of doses received after a 4-month treatment period and reduction in illicit opioid use. Sixteen of the 19 patients analyzed returned for at least one outpatient follow-up after receiving extended-release naltrexone. Of these sixteen patients, two (12.5\%) dropped out after one follow-up session and ten (63\%) remained in treatment for 4 months. The mean number of doses of naltrexone received during the 4 months after initiation was 2.5 (median 3), with twelve patients (75\%) receiving at least two doses. Seven patients (44\%) continued naltrexone beyond 4 months, eleven (69\%) were abstinent or had significant reductions in opioid use, and nine $(56 \%)$ met the criteria for a "good" outcome at 4 months. In terms of safety, the only side effect examined was reports of overdose, of which none were documented.

In order to determine if extended-release naltrexone plus employment-based reinforcement can foster longer-term adherence, DeFulio et a $\mathrm{l}^{44}$ conducted a randomized trial of unemployed heroin-dependent patients $(\mathrm{N}=38)$. Participants were given either extended-release naltrexone (Vivitrol) $(n=19)$ or the same plus a contingency program $(n=19)$ for 24 weeks. The contingency program consisted of a therapeutic workplace where participants could earn vouchers for attendance and participation in training programs. To stay within the program, they were required to receive naltrexone injections at 4-week intervals, but they could earn vouchers independent of their acceptance of naltrexone. Those in the employment-based contingency group accepted significantly more naltrexone injections than those in the naltrexone-only group ( $87 \%$ vs $52 \% ; P=0.002)$ and were more likely to accept the total of six injections ( $74 \%$ vs $26 \% ; P=0.004$ ). However, there was no statistical difference between groups for opiate-negative ( $72 \%$ vs $65 \% ; P=0.56)$ or cocainenegative ( $58 \%$ vs $54 \% ; P=0.75$ ) urine samples.

Using the same experimental protocol, Everly et a ${ }^{45}$ tested the adherence rate to extended-release naltrexone (Depotrex) in conjugation with an employment-based contingency program. Similar to the results of the previous study, the group that received both naltrexone and an employment-based reinforcement accepted significantly more naltrexone injections than the naltrexone-only group ( $81 \%$ vs $42 \% ; P=0.008)$ over the $24-$ week study, and they were more likely to accept all of the injections ( $66 \%$ vs $35 \%$ ). However, both groups had similar numbers of opiate-negative ( $74 \%$ vs $62 \% ; P=0.413$ ) or cocaine-negative ( $56 \%$ vs $54 \%$; $P=0.939)$ urine samples.

\section{Extended-release naltrexone: safety studies}

In the clinical studies summarized, the acute side effects reported following administration of extended-release injectable naltrexone were mainly the same as those observed following oral administration of naltrexone. They included nausea, vomiting, decreased appetite, somnolence, fatigue, headache, dizziness, and anxiety. Systematic reviews of the effectiveness and safety of sustained-release naltrexone for opioid dependence ${ }^{46,47}$ concluded that adverse events of extended-release naltrexone were similar to that of oral naltrexone, but these events were more prominent in the naltrexone groups than in the placebo groups. Several of the studies documented irritation, induration, and pain at the site of injection. These adverse effects were not seen in the placebo groups and thus warnings are currently on the label of Vivitrol. ${ }^{47}$

A potential risk that may be unique to extended-release formulations of naltrexone is the possibility that patients may attempt to remove the medication from within the site of injection. However, to the authors' knowledge, no 
documented cases have appeared in the literature. Other potential side effects may include impairment in liver function and sexual dysfunction. Some early studies using oral formulations of naltrexone have suggested that naltrexone may produce hepatotoxicity and thus current warnings are listed on the prescription label of Vivitrol. ${ }^{48,49}$ Other data have disputed this, ${ }^{50}$ but it is still a boxed warning. There has been no conclusive evidence reported of liver damage in patients receiving the recommended dosages of naltrexone. ${ }^{51,52}$ A report warned of sexual dysfunction with long-term oral naltrexone use, but confirmatory investigation is needed since prior long-term opioid agonist use may have led to the sexual dysfunction. ${ }^{53}$

\section{Opioid overdose}

A concern raised about extended-release naltrexone is opioid agonist overdose. It is cautioned that this may occur in two ways, the first at accustomed doses of opioid agonist due to unanticipated opioid receptor "sensitization" during extended antagonist exposure and the second at unaccustomed high doses of opioid agonist during an intentional attempt to "override" the receptor antagonism. It is well known that in many model systems extended exposure to opioid antagonists can upregulate opioid receptors and increase their density throughout the central nervous system. ${ }^{54-59}$ These changes can result in functional supersensitivity, ${ }^{60,61}$ and an accidental "overdose" may occur even if agonist dose is not increased and antagonist treatment has been discontinued.

An abuser may attempt to override naltrexone's receptor blockade with higher doses of opioid agonists, or by taking opioids at the end of naltrexone's dosing interval, a time when plasma levels are decreasing and the blockade is diminishing. ${ }^{49,62}$ None of the studies presented in this review indicated any overdose cases, but there have been reports of opioid overdose in patients after discontinuation of oral naltrexone maintenance. ${ }^{63,64}$ To further investigate these overdose scenarios, future studies may look to increase follow-up assessments and treatment periods.

\section{Antagonism of pain medication}

Patients who are on extended-release naltrexone have diminished capacity to experience the analgesic effects of opioid agonists. Pain management may become a challenge because analgesia will not be possible with administration of opioids. Patient cases have been reported where successful analgesia was achieved using nonopioid analgesics or a local anesthetic technique. ${ }^{65}$

\section{Conclusion}

Systematic reviews support the safety and efficacy of the "agonist approach" (mainly methadone and buprenorphine), albeit with long-term success rates having been a matter of debate. ${ }^{66-73}$ Less evidence supports the utility of the "antagonist approach" (mainly naltrexone), despite the fact that the approach is seemingly so logical (reduced receptor access to an agonist should attenuate agonist-induced rewarding effects). Part of the problem is that a high level of motivation and compliance is necessary.

Naltrexone initially was available only in an oral formulation. A once-monthly injectable (depot) form was developed in order to improve the chances of compliance. The FDA approved Vivitrol in October 2010 for prevention of relapse to opioid dependence following opioid detoxification, to be used along with concurrent counseling and social support. Approval was based mainly on a single study and this has generated some criticism of the process. However, the safety and effectiveness of Vivitrol will now be validated, or not, in clinical use. To the authors' knowledge, no controlled studies directly compare the safety and efficacy of the extended-release formulation and the oral formulation, or methadone or buprenorphine maintenance treatment.

Oral naltrexone carries a warning for hepatocellular injury when given in excessive doses and it is contraindicated in acute hepatitis or liver failure; its use in patients with active liver disease must be carefully considered in light of its hepatotoxic effects. Vivitrol does not appear to be a hepatotoxin at the recommended doses, but the margin of separation between the apparently safe dose and the dose causing hepatic injury is stated to be only fivefold or less.

Given the important medical and societal needs for treatment of opioid abuse and the absence of a current $100 \%$ effective treatment, an extended-release opioid antagonist (naltrexone) appears to offer the hope of overcoming the compliance issues of oral naltrexone. Switching from a once-daily (oral) to a once-monthly (injectable) schedule of administration may also provide a psychological advantage, uncoupling drug taking from rewarding effect. Current research does not provide sufficient evidence to make conclusions about the effectiveness or safety of injectable naltrexone in the management of opioid dependence; further research is needed to put this question to rest.

\section{Disclosure}

Dr Pergolizzi is a consultant for ENDO Pharmaceuticals, Baxter Healthcare, Purdue Pharma, King Pharmaceuticals, Johnson and Johnson, and Grünenthal. Prof Raffa is a speaker, consultant, 
and/or basic science investigator for several pharmaceutical companies involved in analgesics research, but receives no royalty (cash or otherwise) from the sale of any product.

\section{References}

1. Substance Abuse and Mental Health Services Administration. Results from the 2010 National Survey on Drug Use and Health: Summary of National Findings. NSDUH Series H-41, HHS Publication No. (SMA) 11-4658. Rockville, MD: Substance Abuse and Mental Health Services Administration; 2011.

2. Stagnitti MN. Trends in Outpatient Prescription Analgesics Utilization and Expenditures for the US Civilian Noninstitutionalized Population, 1996 and 2006. Rockville, MD: Agency for Healthcare Research and Quality; 2009.

3. Centers for Disease Control and Prevention (CDC). Drug overdose deaths: Florida, 2003-2009. MMWR Morb Mortal Wkly Rep. 2011;60(26):869-872.

4. Goldstein A, Herrera J. Heroin addicts and methadone treatment in Albuquerque: a 22-year follow-up. Drug Alcohol Depend. 1995;40(2): 139-150.

5. Hulse GK, English DR, Milne E, Holman CD. The quantification of mortality resulting from the regular use of illicit opiates. Addiction. 1999; 94(2):221-229.

6. Darke S, Ross J. Suicide among heroin users: rates, risk factors and methods. Addiction. 2002;97(11):1383-1394.

7. Schneider JP, Matthews M, Jamison RN. Abuse-deterrent and tamperresistant opioid formulations: what is their role in addressing prescription opioid abuse? CNS Drugs. 2010;24(10):805-810.

8. Hamed E, Moe D. Development of tamper deterrent formulations: state of the pharmaceutical industry. Curr Drug Abuse Rev. 2010;3(3): 139-146.

9. Raffa RB, Pergolizzi JV Jr. Opioid formulations designed to resist/deter abuse. Drugs. 2010;70(13):1657-1675.

10. Kleber HD. Pharmacologic treatments for opioid dependence: detoxification and maintenance options. Dialogues Clin Neurosci. 2007;9(4):455-470.

11. Castells X, Kosten TR, Capellà D, Vidal X, Colom J, Casas M. Efficacy of opiate maintenance therapy and adjunctive interventions for opioid dependence with comorbid cocaine use disorders: a systematic review and meta-analysis of controlled clinical trials. Am J Drug Alcohol Abuse. 2009;35(5):339-349.

12. Amato L, Minozzi S, Davoli M, Vecchi S, Ferri MM, Mayet S. Psychosocial and pharmacological treatments versus pharmacological treatments for opioid detoxification. Cochrane Database Syst Rev. 2008;4:CD005031.

13. Wittchen HU, Apelt SM, Soyka M, et al. Feasibility and outcome of substitution treatment of heroin-dependent patients in specialized substitution centers and primary care facilities in Germany: a naturalistic study in 2694 patients. Drug Alcohol Depend. 2008;95(3):245-257.

14. Mattick RP, Breen C, Kimber J, Davoli M. Methadone maintenance therapy versus no opioid replacement therapy for opioid dependence. Cochrane Database Syst Rev. 2009;3:CD002209.

15. Van den Brink W, Haasen C. Evidenced-based treatment of opioiddependent patients. Can J Psychiatry. 2006;51(10):635-646.

16. Soyka M, Kranzler HR, van den Brink W, Krystal J, Möller HJ, Kasper S; WFSBP Task Force on Treatment, Guidelines for Substance Use Disorders. The World Federation of Societies of Biological Psychiatry (WFSBP) guidelines for the biological treatment of substance use and related disorders: Part 2. Opioid dependence. World J Biol Psychiatry. 2011;12(3):160-187.

17. Nicholls L, Bragaw L, Ruetsch C. Opioid dependence treatment and guidelines. J Manag Care Pharm. 2010;16(1 Supp1 B):S14-S21.

18. Mattick RP, Kimber J, Breen C, Davoli M. Buprenorphine maintenance versus placebo or methadone maintenance for opioid dependence. Cochrane Database Syst Rev. 2003;2:CD002207.
19. Mattick RP, Breen C, Kimber J, Davoli M. Methadone maintenance therapy versus no opioid replacement therapy for opioid dependence. Cochrane Database Syst Rev. 2003;2:CD002209.

20. World Health Organization (WHO). Guidelines for the psychosocially assisted pharmacological treatment of opioid dependence. In: Department of Mental Health and Substance Abuse, editor. Abuse. Geneva: WHO Press; 2009:1-110.

21. Mathers BM, Degenhardt L, Ali H, et al. HIV prevention, treatment, and care services for people who inject drugs: a systematic review of global, regional, and national coverage. Lancet. 2010;375(9719):1014-1028.

22. Friedmann PD, Lemon SC, Stein MD, D'Aunno TA. Accessibility of addiction treatment: results from a national survey of outpatient substance abuse treatment organizations. Health Serv Res. 2003;38(3): 887-903.

23. Peterson JA, Schwartz RP, Mitchell SG, et al. Why don't out-oftreatment individuals enter methadone treatment programmes? Int $J$ Drug Policy. 2010;21(1):36-42.

24. Reece AS. Differing age related trajectories of dysfunction in several organ systems in opiate dependence. Aging Clin Exp Res. Epub February 21, 2011.

25. Toskulkao T, Pornchai R, Akkarapatumwong V, Vatanatunyakum S, Govitrapong P. Alteration of lymphocyte opioid receptors in methadone maintenance subjects. Neurochem Int. 2010;56(2):285-290.

26. Martin WR, Jasinski DR, Mansky PA. Naltrexone, an antagonist for the treatment of heroin dependence: effects in man. Arch Gen Psychiatry. 1973;28(6):784-791.

27. Mello NK, Mendelson JH, Kuehnle JC, Sellers MS. Operant analysis of human heroin self-administration and the effects of naltrexone. J Pharmacol Exp Ther. 1981;216(1):45-54.

28. Walsh SL, Sullivan JT, Preston KL, Garner JE, Bigelow GE. Effects of naltrexone on response to intravenous cocaine, hydromorphone and their combination in humans. $J$ Pharmacol Exp Ther. 1996;279(2): 524-538.

29. Minozzi S, Amato L, Vecchi S, Davoli M, Kirchmayer U, Verster A. Oral naltrexone maintenance treatment for opioid dependence. Cochrane Database Syst Rev. 2006;1:CD001333.

30. Minozzi S, Amato L, Vecchi S, Davoli M, Kirchmayer U, Verster A. Oral naltrexone maintenance treatment for opioid dependence. Cochrane Database Syst Rev. 2011;4:CD001333.

31. Amato L, Minozzi S, Davoli M, Vecchi S, Ferri MM, Mayet S. Psychosocial combined with agonist maintenance treatments versus agonist maintenance treatments alone for treatment of opioid dependence. Cochrane Database Syst Rev. 2008;4:CD004147.

32. Carroll KM, Ball SA, Nich C, et al. Targeting behavioral therapies to enhance naltrexone treatment of opioid dependence: efficacy of contingency management and significant other involvement. Arch Gen Psychiatry. 2001;58(8):755-761.

33. Fals-Stewart W, O'Farrell TJ. Behavioral family counseling and naltrexone for male opioid-dependent patients. J Consult Clin Psychol. 2003;71(3):432-442.

34. Comer SD, Sullivan MA, Hulse GK. Sustained-release naltrexone: novel treatment for opioid dependence. Expert Opin Investig Drugs. 2007;16(8):1285-1294.

35. Brewer C, Streel E. Recent developments in naltrexone implants and depot injections for opiate abuse: the new kid on the block is approaching adulthood. Adicciones. 2010;22(4):285-291.

36. Kelly KI, McBride A. Naltrexone implants. Br J Psychiatry. 2010;196(1): 77; author reply 77 .

37. Kunøe N, Lobmaier P, Vederhus JK, et al. Naltrexone implants after in-patient treatment for opioid dependence: randomised controlled trial. Br J Psychiatry. 2009;194(6):541-546.

38. Waal H, Frogopsahl G, Olsen L, Christophersen AS, Mørland J. Naltrexone implants: duration, tolerability and clinical usefulness; a pilot study. Eur Addict Res. 2006;12(3):138-144.

39. Comer SD, Collins ED, Kleber HD, Nuwayser ES, Kerrigan JH, Fischman MW. Depot naltrexone: long-lasting antagonism of the effects of heroin in humans. Psychopharmacology (Berl). 2002;159(4):351-360. 
40. Comer SD, Sullivan MA, Yu E, et al. Injectable, sustained-release naltrexone for the treatment of opioid dependence: a randomized, placebo-controlled trial. Arch Gen Psychiatry. 2006;63(2):210-218.

41. Brooks AC, Comer SD, Sullivan MA, et al. Long-acting injectable versus oral naltrexone maintenance therapy with psychosocial intervention for heroin dependence: a quasi-experiment. J Clin Psychiatry. 2010;71(10):1371-1378.

42. Krupitsky E, Nunes EV, Ling W, Illeperuma A, Gastfriend DR, Silverman BL. Injectable extended-release naltrexone for opioid dependence: a double-blind, placebo-controlled, multicentre randomised trial. Lancet. 2011;377(9776):1506-1513.

43. Fishman MJ, Winstanley EL, Curran E, Garrett S, Subramaniam G. Treatment of opioid dependence in adolescents and young adults with extended release naltrexone: preliminary case-series and feasibility. Addiction. 2010;105(9):1669-1676.

44. DeFulio A, Everly JJ, Leoutsakos JM, et al. Employment-based reinforcement of adherence to an FDA approved extended release formulation of naltrexone in opioid-dependent adults: a randomized controlled trial. Drug Alcohol Depend. Epub July 20, 2011.

45. Everly JJ, DeFulio A, Koffarnus MN, et al. Employment-based reinforcement of adherence to depot naltrexone in unemployed opioid-dependent adults: a randomized controlled trial. Addiction. 2011;106(7):1309-1318.

46. Lobmaier P, Kornør H, Kunøe N, Bjørndal A. Sustained-release naltrexone for opioid dependence. Cochrane Database Syst Rev. 2008;2:CD006140.

47. Lobmaier PP, Kunøe N, Gossop M, Waal H. Naltrexone depot formulations for opioid and alcohol dependence: a systematic review. CNS Neurosci Ther. Epub September 23, 2010.

48. Malcolm R, O’Neil PM, Sexauer JD, Riddle FE, Currey HS, Counts C. A controlled trial of naltrexone in obese humans. Int J Obes. 1985;9(5): 347-353.

49. Vivitrol (naltrexone for extended-release injectable suspension) [prescribing information]. Dublin, Ireland: Alkermes Inc; 2010.

50. Brewer C, Wong VS. Naltrexone: report of lack of hepatotoxicity in acute viral hepatitis, with a review of the literature. Addict Biol. 2004; 9(1):81-87.

51. Yen MH, Ko HC, Tang FI, Lu RB, Hong JS. Study of hepatotoxicity of naltrexone in the treatment of alcoholism. Alcohol. 2006;38(2): $117-120$.

52. Garbutt JC. Efficacy and tolerability of naltrexone in the management of alcohol dependence. Curr Pharm Des. 2010;16(19):2091-2097.

53. Ramdurg S, Ambekar A, Lal R. Sexual dysfunction among male patients receiving buprenorphine and naltrexone maintenance therapy for opioid dependence. J Sex Med. Epub March 2, 2011.

54. Sirohi S, Kumar P, Yoburn BC. Mu-opioid receptor up-regulation and functional supersensitivity are independent of antagonist efficacy. J Pharmacol Exp Ther. 2007;323(2):701-707.

55. Zaki PA, Keith DE Jr, Brine GA, Carroll FI, Evans CJ. Ligand-induced changes in surface mu-opioid receptor number: relationship to $\mathrm{G}$ protein activation? J Pharmacol Exp Ther. 2000;292(3):1127-1134.

56. Rajashekara V, Patel CN, Patel K, Purohit V, Yoburn BC. Chronic opioid antagonist treatment dose-dependently regulates mu-opioid receptors and trafficking proteins in vivo. Pharmacol Biochem Behav. 2003;75(4):909-913.
57. Yoburn BC, Shah S, Chan K, Duttaroy A, Davis T. Supersensitivity to opioid analgesics following chronic opioid antagonist treatment: relationship to receptor selectivity. Pharmacol Biochem Behav. 1995;51(2-3):535-539.

58. Lesscher HM, Bailey A, Burbach JP, Van Ree JM, Kitchen I, Gerrits MA. Receptor-selective changes in mu-, delta- and kappa-opioid receptors after chronic naltrexone treatment in mice. Eur J Neurosci. 2003; 17(5):1006-1012.

59. Patel CN, Rajashekara V, Patel K, Purohit V, Yoburn BC. Chronic opioid antagonist treatment selectively regulates trafficking and signaling proteins in mouse spinal cord. Synapse. 2003;50(1):67-76.

60. Yoburn BC, Inturrisi CE. Modification of the response to opioid and nonopioid drugs by chronic opioid antagonist treatment. Life Sci. 1988; 42(18):1689-1696.

61. Yoburn BC, Kreuscher SP, Inturrisi CE, Sierra V. Opioid receptor upregulation and supersensitivity in mice: effect of morphine sensitivity. Pharmacol Biochem Behav. 1989;32(3):727-731.

62. Fishman M. Precipitated withdrawal during maintenance opioid blockade with extended release naltrexone. Addiction. 2008;103(8): 1399-1401.

63. Digiusto E, Shakeshaft A, Ritter A, O'Brien S, Mattick RP; NEPOD Research Group. Serious adverse events in the Australian National Evaluation of Pharmacotherapies for Opioid Dependence (NEPOD). Addiction. 2004;99(4):450-460.

64. Ritter AJ. Naltrexone in the treatment of heroin dependence: relationship with depression and risk of overdose. Aust N Z J Psychiatry. 2002; 36(2):224-228.

65. O'Brien B, Cody C. Analgesia and sedation in the presence of a naltrexone implant: a novel pharmacological challenge. Eur J Emerg Med. 2006;13(5):315-316.

66. Ward J, Mattick RP, Hall W. The effectiveness of methadone maintenance treatment: an overview. Drug Alcohol Rev. 1994;13(3):327-335.

67. Fiellin DA, Moore BA, Sullivan LE, et al. Long-term treatment with buprenorphine/naloxone in primary care: results at 2-5 years. Am J Addict. 2008;17(2):116-120.

68. Hubbard RL, Marsden ME, Cavanaugh E, Rachal JV, Ginzburg HM. Role of drug-abuse treatment in limiting the spread of AIDS. Rev Infect Dis. 1988;10(2):377-384.

69. Simpson DD, Joe GW, Broome KM. A national 5-year follow-up of treatment outcomes for cocaine dependence. Arch Gen Psychiatry. 2002;59(6):538-544.

70. Simpson DD. Treatment for drug abuse: follow-up outcomes and length of time spent. Arch Gen Psychiatry. 1981;38(8):875-880.

71. Hubbard RL, Craddock SG, Anderson J. Overview of 5-year followup outcomes in the drug abuse treatment outcome studies (DATOS). $J$ Subst Abuse Treat. 2003;25(3):125-134.

72. Gottheil E, Sterling RC, Weinstein SP. Diminished illicit drug use as a consequence of long-term methadone maintenance. J Addict Dis. 1993;12(4):45-57.

73. Maremmani I, Pani PP, Pacini M, Perugi G. Substance use and quality of life over 12 months among buprenorphine maintenance-treated and methadone maintenance-treated heroin-addicted patients. J Subst Abuse Treat. Jul 2007;33(1):91-98.
Substance Abuse and Rehabilitation

\section{Publish your work in this journal}

Substance Abuse and Rehabilitation is an international, peer-reviewed, open access journal publishing original research, case reports, editorials, reviews and commentaries on all areas of addiction and substance abuse and options for treatment and rehabilitation. The manuscript management system is completely online and includes a very quick and fair

\section{Dovepress}

peer-review system. Visit http://www.dovepress.com/testimonials.php to read real quotes from published authors. 